\title{
A Design of a 345-kV Electric Power Transmission Line Interlinking Ramu and Rouna Grids in Papua New Guinea
}

\author{
Francis Sakato ${ }^{1}$, Joseph Fisher ${ }^{2}$, Paul RP Hoole ${ }^{3, a}$, Martin Anyi ${ }^{3}$ and Samuel RH Hoole ${ }^{4}$ \\ ${ }^{1}$ Telikom PNG Limited, Papua New Guinea \\ ${ }^{2}$ Department of Electrical and Communication Engineering - Papua New Guinea University of Technology, Papua New Guinea \\ ${ }^{3}$ Department of Electrical and Electronic Engineering - Universiti Malaysia Sarawak, Malaysia \\ ${ }^{4}$ Department of Electrical and Computer Engineering - Michigan State University, USA
}

\begin{abstract}
According to PNG Power Limited (PPL), Papua New Guinea's peak power demand is expected to increase from $210 \mathrm{MW}$ in 2012 to $347 \mathrm{MW}$ in 2026. Under the current state of the power sector in Papua New Guinea (PNG), it is critical to implement measures to cope with the increasing power demand to promote investment, economic growth, and ultimately to achieve poverty reduction through economic growth. One of the solutions identified to improve the reliability of PNG power systems and thus to meet the demand is to interconnect the major grids in the country so that the loads could be shared among them. This project embarks in designing a $345-\mathrm{kV}$ electric power transmission line to interlink the Ramu and Rouna power grids of Papua New Guinea. The design is done by analysing all the necessary aspects of the transmission lines with in-depth calculations performed using MATHCAD software. This design is the basis for extra-high voltage (EHV) transmission network in anticipation for the power generation and demand growth in PNG.
\end{abstract}

\section{Introduction}

Reliable and efficient supply of electricity is a key pillar in stimulating economic development and growth in any country in the world. In PNG however, the growth and sustainability of the economy is often discouraged because of certain key development issues and challenges in the power sector. For instance, due to the rugged geography of PNG the cost of building infrastructures to extend power to off-grid areas is substantial. Meanwhile, aging of the existing infrastructures causes a lot of power losses and reliability issues in the system.

Moreover, due to the isolated power grids in PNG the emergency or standby generating capacities are stretched to the limit in the event of scheduled or emergency shutdowns. Consequently load shedding has become very consistent and frequent hence disrupting daily business operations and leaving consumers dissatisfied with the electricity service provided.

\section{Ongoing Interconnection Project}

The power sector of PNG comprises of two main networks: (i) Port Moresby and (ii) the Ramu system, having peak loads of about $150 \mathrm{MW}$ and $80 \mathrm{MW}$ respectively. These two systems are separated by the Owen Stanley mountain range, which has acted as a formidable constraint against the development of crucial infrastructure within the country.

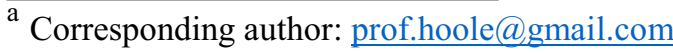

The PNG map on Figure 1 shows the proposed transmission line route of a possible interconnection, running south from Baiune (Morobe) to Port Moresby. The existing power grid extends further south of Baiune, through Bulolo and on to Wau, about 30 to $40 \mathrm{~km}$ to the south. The Hidden Valley mining development, which began operations in 2009 , lies a further $20 \mathrm{~km}$ to the south. Thus, a $132-\mathrm{kV}$ line to provide $15 \mathrm{MW}$ power to the mine will have covered a substantial distance into the mountains.

The last interconnection analysis was conducted in 1990 by the Électricité de France (EDF) and came up with the following recommendations for the transmission system [1]:

(a) A $288 \mathrm{~km}$ long $220-\mathrm{kV}$ line connecting Wau in the Ramu system to Moitaka in the Port Moresby system;

(b) $220 / 132-\mathrm{kV}$ substations at Singsing, Nadzab and Wau in the Ramu system and a $220 / 66-\mathrm{kV}$ substation at Moitaka;

(c) Shunt reactors at each end of the tie line - 30 MVAR at Wau and 20 MVAR at Moitaka;

(d) The upgrading to $220-\mathrm{kV}$ of the double circuit line between Nadzab and Singsing to transmit Ramu 2 hydropower to Nadzab and then to Port Moresby.

EDF found that interconnection was viable once the Port Moresby load reached about 120 MW in 2005, with the transfer capacity of the transmission line being about 80 MW. Currently the Port Moresby load demand has peaked $150 \mathrm{MW}$ a day which will continue to rise into 
the foreseeable future. PNG Power Limited (PPL) which is the sole power utility company that provides electricity services in the country reported that PNG's peak power demand is expected to increase from $210 \mathrm{MW}$ in 2012 to $347 \mathrm{MW}$ in 2026 [2]. All these truly call for the interconnection to be made between these two isolated power grids.

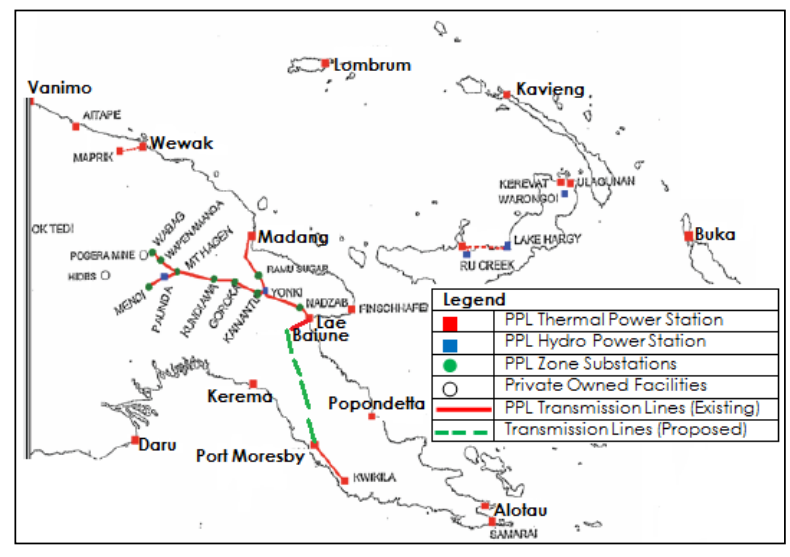

Figure 1. PNG Map showing the proposed transmission line in dotted green lines (Source: PPL, Planning Department, 2008).

\section{Project Justification}

PNG Power Limited (PPL) which oversees about 300 MW of total 582 MW power capacity in the country has seen a steady growth of power consumption in the recent years. PPL had an overall growth of 756 million $\mathrm{kWh}$ in 2004 and in the year 2005, it had grown to about 779 million $\mathrm{kWh}$, or by $3 \%$. A 12 -month period ending May 2008 totalled 825 million $\mathrm{kWh}$ which represents about $2.3 \%$ annual growth over a 2.5 year period. The customer numbers continued to increase during this period because of rural electrification efforts by PPL (National \& Provincial Ten Year Power Development Plan (2007-16), PNG Power Limited, 2006) [1-2]. Ultimately, the demand is projected to grow gradually well into the future.

As the loads grow it is necessary to interconnect the separate power system grids that are serving PNG to make possible the integrated operation of these systems. The interconnections permit the use of generators of large ratings that can supply energy at low cost. It minimizes the amount of reserve generating capacity required to maintain service by sharing the load in the event of scheduled or emergency outages of generation. Adequate transmission makes this possible by making available other sources of generation hence the transmission capability required must at the minimum remain in proportion to the system capability. The significance of transmission and adequate interconnections where economically justified provide the key to large-scale, low-cost generating units, to major savings in capacity due to load diversity (sharing), and to the most efficient utilization of existing generating capacity. In short, interconnection is the coordinating medium that makes possible the most efficient use of facilities in any area or region [3].
Furthermore Papua New Guinea is endowed with diverse renewable energy sources which have the potential to meet every household energy needs in the country as well as exporting excess to neighbouring regions such as West Papua (Indonesia) and Australia. The Stanley Gas Project in the Western Province, South East Mananda gas fired plant in the Southern Highlands Province and the Purari hydro scheme are some of the massive projects under feasibility studies which when streamlined will potentially deliver more than $2000 \mathrm{MW}$ of electricity.

The Purari Hydro Scheme has huge output (over 2000 MW) which could feed into the Port Moresby and Highlands grids and allow for the development of new industries, particularly in the Southern Region, as well as the export of electricity to Australia. Power from the scheme could also provide electricity to local communities at the early stages and when fully operational could supply well over 300,000 families [4].

Moreover, the Mananda and Ramu System could increase total output to as much as $497 \mathrm{MW}$. These projects will certainly transform the local economies as well as the national economy, and improve the lives of the bulk of population in the long term [5].

Apparently, PNG also has great potential in geothermal energy which will significantly boost the generation capacity in the country. In the Talasea region of West New Britain Province prefeasibility studies have established up to $4000 \mathrm{MW}$ of geothermal power [6]. This power will form the New Britain Grid where it will connect with Rabaul (East New Britain Province) and then undersea (submarine) cable can take it to New Ireland Province, all the way to Bougainville and the Solomon Islands. The New Britain Grid will also interconnect with the Ramu Grid via undersea cables to Lae. (B. Micah - The National, October 2, 2015).

Indeed it is true that PNG has huge energy potential that needs to be utilized to not only electrify the entire country but export excess energy to Australia, Solomon Islands and Indonesia. When PNG develops a TransNational and Trans-Regional grids to effectively and reliably transport the energy from the different energy sources to load centres, the money return from such incentives would certainly boost the economy.

Hence, this project is undertaken to embrace these opportunities by designing a $345-\mathrm{kV}$ transmission line to interlink Ramu and Rouna Grids. This transmission line will subsequently serve as the main electrical transmission artery for bulk power transfer right across the country and to the neighbouring West Irian, Australia and Solomon Islands. The result of this will certainly develop into the proposed Trans-National and TransRegional Grids in which PNG will play a crucial role in clean energy production through its substantial renewable energy potential.

\subsection{Proposed Route}

The route that was proposed in this project is shown in the map below (Figure 2). The route was proposed from Port Moresby to Kerema to Ialibu. There are many 
factors that influenced the selection of this route but the two very compelling ones are;

(i) The route was proposed to run near the corridors of some of the potential power generation sources so that the power could be transferred easily to the various load centres (the blue stars in the map indicate some of these potential generation sources that are under feasibility studies); and

(ii) This route is selected to develop a Trans-National Grid and subsequently and Trans-Regional Grid as stated earlier.

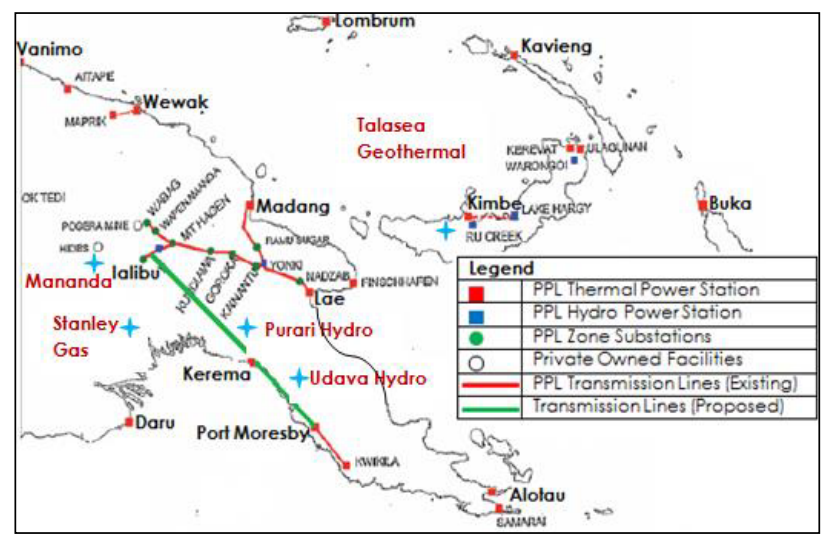

Figure 2. Proposed 345-kV transmission line route.

The previous route proposed by EDF can also be used as an alternative route for the $345-\mathrm{kV}$ transmission line. The ultimate aim is to develop a grid that can connect the entire country so that every household can have access to electricity. Countries similar to PNG in terms of geographic challenges have connected their population to their national grids. There is no exception for PNG because the technology is already at our disposal to develop and implement such impact projects to improve living standards and grow a sustainable economy.

\subsection{Proposed Transmission Line Facilities}

The proposed $345-\mathrm{kV}$ transmission line is summarized in Table 1. The new transmission line would extend, in overhead configurations, for approximately $555.56 \mathrm{~km}$ from Port Moresby to Gulf to Ialibu in the Southern Highlands Province. And from Ialibu, the new 345-kV line would be stepped down to PPL's existing overhead $66-\mathrm{kV}$ transmission line.

Table 1. Proposed 345-kV Transmission Line

\begin{tabular}{|c|c|c|}
\hline $\begin{array}{c}\text { Proposed } \\
\text { Line } \\
\text { Number }\end{array}$ & Line Description & $\begin{array}{c}\text { Line } \\
\text { Voltage }\end{array}$ \\
\hline 001 & $\begin{array}{c}\text { Rouna Substation to Kerema } \\
\text { (Proposed) Switching Station }\end{array}$ & $345-\mathrm{kV}$ \\
\hline 002 & $\begin{array}{l}\text { Kerema Switching Station to } \\
\text { Ialibu (Proposed) Substation }\end{array}$ & $345-\mathrm{kV}$ \\
\hline 003 & $\begin{array}{c}\text { Ialibu (Walum) Substation to } \\
\text { Ramu Substation }\end{array}$ & $66-\mathrm{kV}$ \\
\hline
\end{tabular}

Approximately $43 \%(238 \mathrm{~km})$ of the proposed route for the new transmission lines would be located entirely within existing road infrastructure (Rouna to Kerema). The remaining $57 \%$ is along corridors of proposed road links to be built and presently construction is underway (Gulf to SHP).

\section{Transmission Line Design Calculations}

The following sections are some samples of design calculations performed for the $345-\mathrm{kV}$ electric power transmission line to interlink Ramu and Rouna Grids.

\subsection{5-kV Line Characteristics}

Table 2 summarizes the $345-\mathrm{kV}$ line characteristics for subsequent calculations that follow henceforth.

Table 2. EHV Line Characteristics for $345-\mathrm{kV} 3 \mathrm{H} 2$ Tower type [3].

\begin{tabular}{|c|c|}
\hline $\begin{array}{l}\text { Mechanical \& Electrical } \\
\text { Components }\end{array}$ & 345-kV Line Characteristics \\
\hline $\begin{array}{c}\text { Transmission Line } \\
\text { Distance (Pom to Ialibu) } \\
\text { Altitude }\end{array}$ & $\begin{array}{c}\text { 345-kV AC, 3-phase, } 50 \mathrm{~Hz} \\
555.56 \mathrm{~km} \\
0-3000 \mathrm{~m}\end{array}$ \\
\hline $\begin{array}{c}\text { Structures } \\
\text { Tower type } \\
\text { Material } \\
\text { Average tower span } \\
\text { Average weight/structure } \\
\text { Tower height } \\
\text { Distance between tower } \\
\text { Designed for }\end{array}$ & $\begin{array}{c}3 \mathrm{H} 2 \\
\text { Steel } \\
268 \mathrm{~m} \\
4763 \mathrm{~kg} \\
22.25 \mathrm{~m} \\
8.687 \mathrm{~m} \\
\text { Single-circuit H-configuration }\end{array}$ \\
\hline $\begin{array}{l}\text { Minimum Clearance } \\
\text { Phase to tower } \\
\text { Phase to ground } \\
\text { Phase to phase }\end{array}$ & $\begin{array}{l}4.115 \mathrm{~m} \\
2.896 \mathrm{~m} \\
8.23 \mathrm{~m}\end{array}$ \\
\hline $\begin{array}{c}\text { Conductor } \\
\text { Type: } \\
\text { No. of conductors/phase; } \\
\text { Spacing } \\
\text { Code Name } \\
\text { Conductor weight } \\
\text { Conductor diameter } \\
\text { Current Rating Per phase } \\
\text { Average span length }\end{array}$ & $\begin{array}{c}\text { ACSR } \\
2 ; \\
45.7 \mathrm{~cm} \\
\text { Lapwing } \\
2.667 \mathrm{~kg} / \mathrm{m} \\
0.038 \mathrm{~m}(38 \mathrm{~mm}) \\
1354 \mathrm{Amps} \\
304.8 \mathrm{~m}\end{array}$ \\
\hline $\begin{array}{c}\text { Insulators (Suspension } \\
\text { Strings) } \\
\text { Configuration } \\
\text { No. of strings/phase } \\
\text { No. of units/string }\end{array}$ & $\begin{array}{c}\mathrm{I} \\
1 \\
18-24\end{array}$ \\
\hline
\end{tabular}




\begin{tabular}{|c|c|}
\hline Lightning Protection & \\
No. of shield wires & 2 \\
Material type & Alumoweld \\
Diameter & $1.2 \mathrm{~cm}$ \\
Tower footing resistance & $<10 \mathrm{ohms}$ \\
\hline Right-of-Way & $76.2 \mathrm{~m}$ \\
& $45.72 \mathrm{~m}-$ minimum \\
\hline
\end{tabular}

\subsection{Clearance Calculation}

The purpose of this study is to determine the number of insulators and verify the clearances for transmission tower type $3 \mathrm{H} 2$ with a transmission voltage of $345-\mathrm{kV}$ to operate in an area of moderate pollution level. The transmission tower structure is shown in Figure 3.

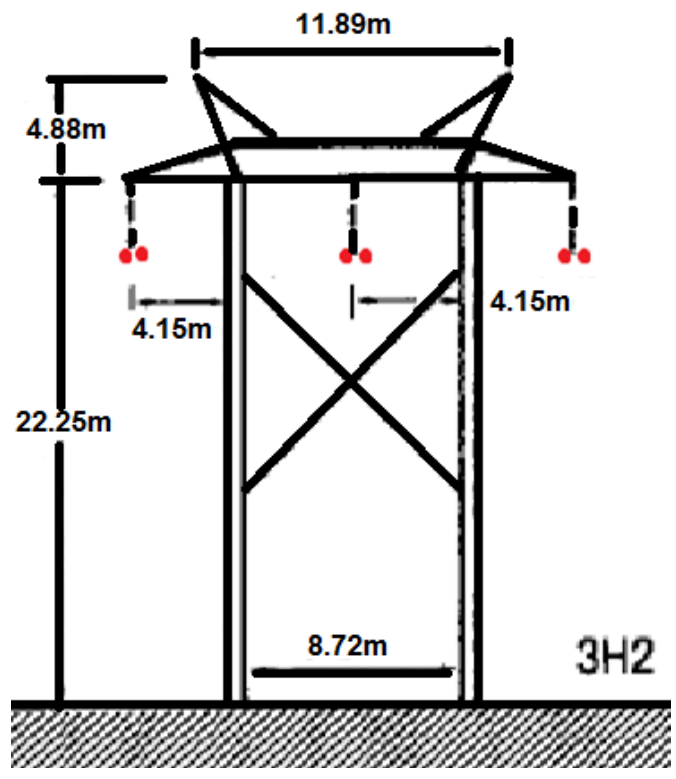

Figure 3. Transmission tower type $3 \mathrm{H} 2$ selected.

IEEE Standard 1313.2-1999 Application of Insulation Coordination recommends maximum operating voltages BSL and BIL levels [7].

- The maximum phase-to-phase voltage is: $\mathrm{Vmax}=$ $362 \mathrm{kV}$

- The maximum switching surge voltage to ground is (BSL): VBSLg $=850 \mathrm{kV}$

- The basic insulation level (BIL), for lightning generated overvoltage is: $\mathrm{VBIL}=1050 \mathrm{kV}$

The insulator manufacturers suggest leakage distance for different insulators at different pollution levels. Also standards recommend leakage distance for different pollution levels. IEEE Standard 1313.2-1999 Application of Insulation Coordination recommends number of insulators or leakage distance at different contamination levels.

Table 3. Power frequency strength of insulator strings $(\mathrm{kV} / \mathrm{m}$ connecting length) [7].

\begin{tabular}{|c|c|c|c|c|}
\hline \multirow{2}{*}{ Classification } & \multirow{2}{*}{$\begin{array}{c}\text { Severity, } \\
\mathbf{m g} / \mathbf{c m}^{2}\end{array}$} & \multicolumn{2}{|c|}{$\begin{array}{c}\text { Standard units } \\
\mathbf{( k V / m )} \mathbf{3} \text { 3/4 x 10" }\end{array}$} & $\begin{array}{c}\text { High- } \\
\text { leakage } \\
\text { units }\end{array}$ \\
\cline { 3 - 5 } & & I-string & $\begin{array}{c}\text { V- } \\
\text { string }\end{array}$ & \\
\hline Very light & 0.03 & 86.9 & 98.6 & $91-99$ \\
\hline Light & 0.06 & 67.5 & 82.0 & $74-88$ \\
\hline Moderate & 0.10 & 59.3 & 74.8 & $64-82$ \\
\hline Heavy & 0.40 & 49.3 & 66.0 & $56-73$ \\
\hline
\end{tabular}

Table 4. Number of standard units required [7].

\begin{tabular}{|c|c|c|c|c|}
\hline \multirow{2}{*}{$\begin{array}{c}\text { System } \\
\text { voltage, } \\
\text { kV }\end{array}$} & \multicolumn{4}{|c|}{$\begin{array}{c}\text { Number of standard units for a } \\
\text { contamination severity: I-strings/V-strings }\end{array}$} \\
\cline { 2 - 5 } & $\begin{array}{c}\text { Very } \\
\text { Light }\end{array}$ & Light & Moderate & Heavy \\
\hline 138 & $6 / 6$ & $8 / 7$ & $9 / 7$ & $11 / 8$ \\
\hline 161 & $7 / 7$ & $10 / 8$ & $11 / 9$ & $13 / 10$ \\
\hline 230 & $11 / 10$ & $14 / 12$ & $16 / 13$ & $19 / 15$ \\
\hline 345 & $16 / 15$ & $21 / 17$ & $24 / 19$ & $29 / 22$ \\
\hline 500 & $25 / 22$ & $32 / 27$ & $37 / 29$ & $44 / 33$ \\
\hline 765 & $36 / 32$ & $47 / 39$ & $53 / 42$ & $64 / 48$ \\
\hline
\end{tabular}

\subsubsection{Insulator Selection}

The moderate pollution level permits the use of standard insulators. The data of the 5.75"x10" insulators are:

$$
\begin{aligned}
& \text { Diameter }=254 \mathrm{~mm} \quad \mathrm{D}_{\text {connection }}=146.05 \mathrm{~mm} \\
& \mathrm{D}_{\text {leakage }}:=292 \mathrm{~mm}
\end{aligned}
$$

Using Table 3 the recommended connection distance of flashover strength for moderate industrial pollution using standard insulators in vertical position is:

$$
\mathrm{D}_{\text {flash_con }}:=59.3 \frac{\mathrm{kV}}{\mathrm{m}}
$$

Limitations on the entrance bushing restricted the maximum phase to phase voltage in the insulator chamber to:

$$
\mathrm{V}_{\ln }:=\frac{362 \mathrm{kV}}{\sqrt{3}}
$$

Therefore, the required connection distance of the insulator string (chain) is:

$$
\begin{aligned}
& \mathrm{D}_{\text {chain }}:=\frac{\mathrm{V}_{\text {ln }}}{\mathrm{D}_{\text {flash_con }}} \\
& \mathrm{D}_{\text {chain }}=352.447 \mathrm{~cm}
\end{aligned}
$$

Hence the required number of insulators is: 


$$
\begin{aligned}
& \mathrm{N}_{345 \mathrm{kV}}:=\frac{\mathrm{D}_{\text {chain }}}{\mathrm{D}_{\text {connection }}} \\
& \mathrm{N}_{345 \mathrm{kV}}=24.132
\end{aligned}
$$

Based on the calculations performed above, the required number of insulators is 24 . This is in accordance to the established IEEE Standard 1313.2-1999 given in Table 4 which suggests that 24 I-string insulators be used for $345-\mathrm{kV}$ transmission line at moderate pollution level. We therefore recommend 24 I-string standard insulators for this project.

\subsubsection{Clearance Calculation}

\section{Wind Force - Horizontal}

A moderate loading area is considered for this $345-\mathrm{kV}$ EHV transmission line because of the inevitability of smoke, salt deposits and dusts from the gravel roads.

The weight of the wind force per square meter is given below.

$$
\begin{aligned}
& \mathrm{F}_{\text {wind_Med }}:=4 \frac{\mathrm{lb}}{\mathrm{ft}^{2}} \quad \text { Temp }:=15 \mathrm{~F} \\
& \text { Area }_{\text {wind }}:=\mathrm{d}_{\text {cond }} \cdot \text { Span } \\
& \text { Area }{ }_{\text {wind }}=23.288 \mathrm{~m}^{2} \\
& \mathrm{~F}_{\text {wind }}:=\text { Area }_{\text {wind }} \cdot \mathrm{F}_{\text {wind_Med }} \\
& \mathrm{F}_{\text {wind }}=454.802 \mathrm{~kg}
\end{aligned}
$$

$$
\begin{aligned}
& \mathrm{W}_{\text {wire }}:=\mathrm{w} \cdot \mathrm{Span} \\
& \mathrm{W}_{\text {wire }}=1.627 \times 10^{3} \mathrm{~kg}
\end{aligned}
$$

We are not anticipating any ice loads because of our tropical climate hence the total vertical force $\left(\mathrm{F}_{\mathrm{ver}}\right)$ is due to the weight force $\left(\mathrm{W}_{\text {wire }}\right)$ only.

$$
\begin{aligned}
& \mathrm{F}_{\text {ver }}:=\mathrm{W}_{\text {wire }} \\
& \mathrm{F}_{\text {ver }}=1.627 \times 10^{3} \mathrm{~kg}
\end{aligned}
$$

The angle deviation when the conductor sways away from its initial position due to the two forces above is given below.

$$
\begin{aligned}
& \phi_{\text {cond }}:=\operatorname{atan}\left(\frac{F_{\text {wind }}}{F_{\text {ver }}}\right) \\
& \phi_{\text {cond }}=15.62 \mathrm{ldeg}
\end{aligned}
$$

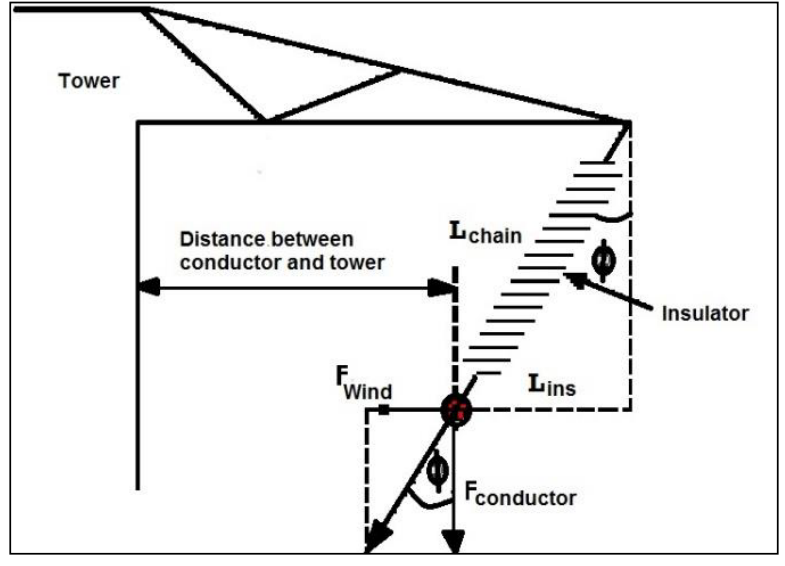

Figure 4. Distance between conductor and structure.

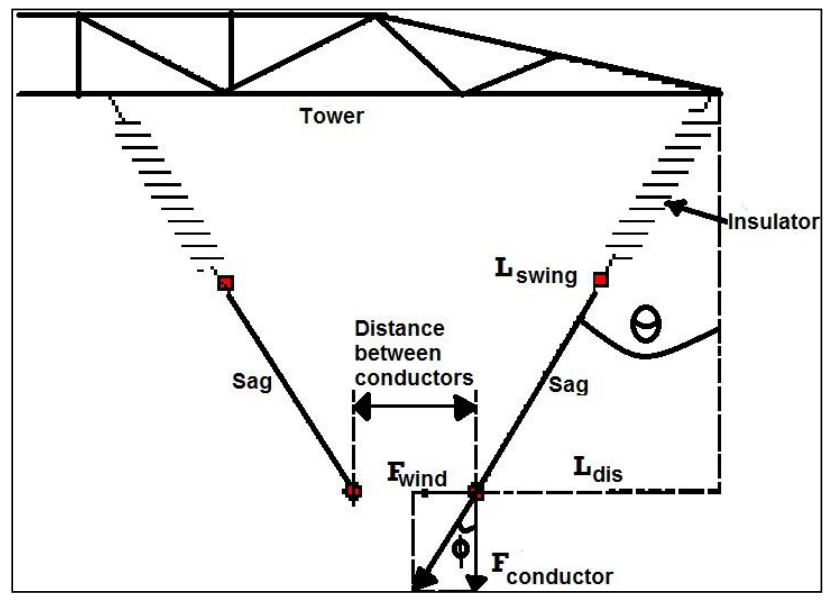

Figure 5. Distance between conductors.

It is assumed that the conductors swing to each other. Phase angle is 180 degrees. The total length is:

$$
\begin{gathered}
\mathrm{L}_{\text {chain }}:=24 \mathrm{D}_{\text {connection }} \\
\mathrm{L}_{\text {chain }}=3.505 \mathrm{~m} \\
\mathrm{~L}_{\text {ins }}:=\mathrm{L}_{\text {chain }} \cdot \sin \left(\phi_{\text {cond }}\right) \\
\mathrm{L}_{\text {ins }}=0.944 \mathrm{~m} \\
\mathrm{D}_{\text {tower_cond }}:=\mathrm{D}_{\text {con_str }}-\mathrm{L}_{\text {ins }} \\
\mathrm{D}_{\text {tower_cond }}=3.171 \mathrm{~m} \\
\mathrm{~L}_{\text {Swing }}:=\mathrm{L}_{\text {ins }}+\mathrm{Sag} 60 \mathrm{~F} \\
\mathrm{~L}_{\text {Swing }}=0.944 \mathrm{~m} \\
\mathrm{~L}_{\text {dis }}:=\mathrm{L}_{\text {Swing }} \cdot \sin \left(\phi_{\text {cond }}\right) \\
\mathrm{L}_{\text {dis }}=0.254 \mathrm{~m} \\
\text { Dis } \\
\text { Dis } \\
\text { cond }
\end{gathered}
$$




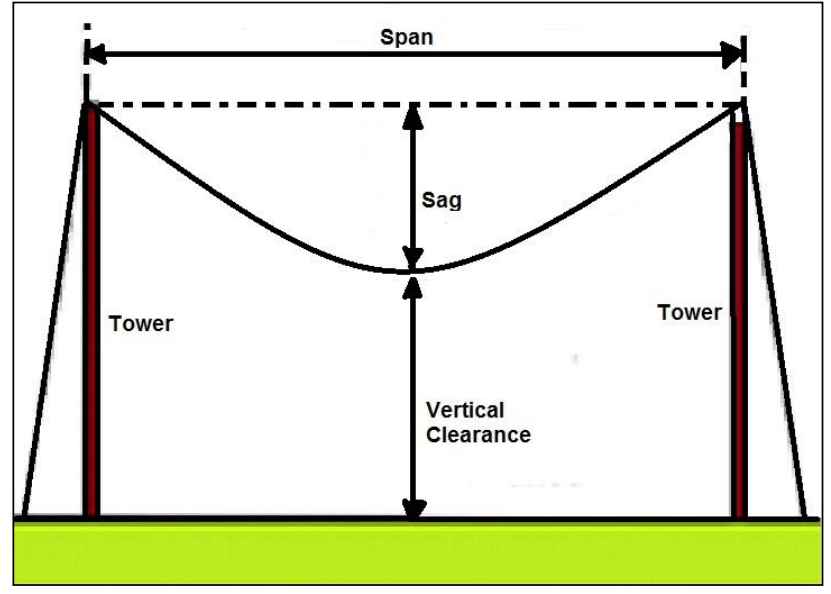

Figure 6. Distance between conductors and ground.

$$
\begin{aligned}
& \text { Vertical_Clearance }:=\mathrm{H}_{\text {tower }}-\mathrm{L}_{\text {chain }}-\mathrm{Sag}_{60 \mathrm{~F}} \\
& \text { Vertical_Clearance }=18.745 \mathrm{~m}
\end{aligned}
$$

For Figure 4 and Figure 5, the recommended safety clearances of the I-insulator strings are $2.5 \mathrm{~m}$ and $2.6 \mathrm{~m}$ respectively. The calculations for this design show a safety clearance of $3.171 \mathrm{~m}$ and $7.721 \mathrm{~m}$ respectively which are reasonably much safer. And for Figure 6, the vertical clearance of the conductor from the ground taking into account the I-string insulator length and the sag at $60^{\circ} \mathrm{F}$ is $61.5 \mathrm{ft}$. $(18.745 \mathrm{~m})$ which is within the safety distance specified by the National Safety Code.

\subsection{Electric Field Calculation}

The three-phase line generated field calculation is performed and the $\mathrm{x}$ - and $\mathrm{y}$-component of the field generated by each conductor are added together. The resulting electric field vector is calculated subsequently.

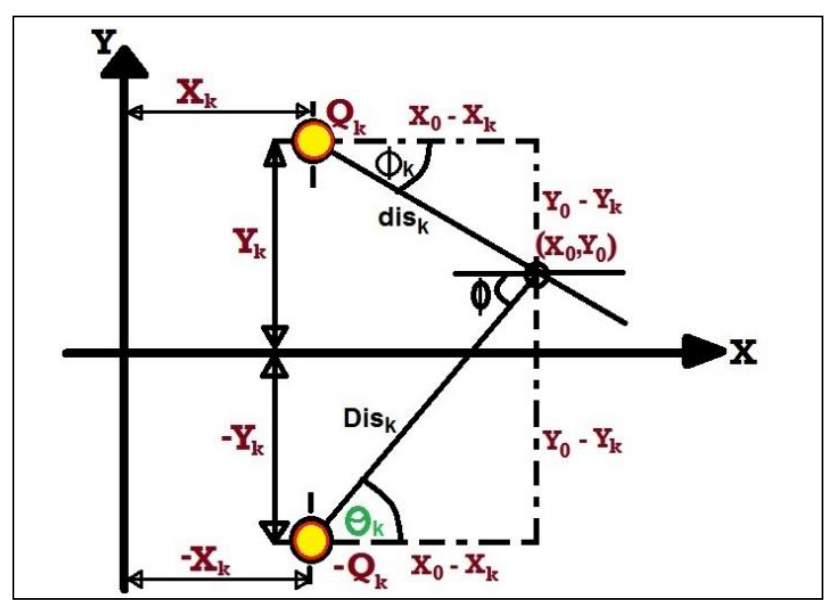

Figure 7. The vector axes of the electric field.

Field generated by the positive charges on the conductors

Distance between conductor $k$ and a selected point with coordinates of $\left(\mathrm{x}_{\mathrm{o}}, \mathrm{y}_{\mathrm{o}}\right)$.

$$
\begin{aligned}
& \mathrm{k}:=0 . .4 \\
& \operatorname{dis}\left(\mathrm{x}_{\mathrm{O}}, \mathrm{y}_{\mathrm{O}}, \mathrm{k}\right):=\sqrt{\left(\mathrm{x}_{\mathrm{O}}-\mathrm{x}_{\mathrm{k}}\right)^{2}+\left(\mathrm{y}_{\mathrm{O}}-\mathrm{y}_{\mathrm{k}}\right)^{2}} \\
& \operatorname{dis}\left(\mathrm{x}_{\mathrm{O}}, \mathrm{y}_{\mathrm{O}}, \mathrm{k}\right)= \\
& \hline 75.4321 \\
& \hline 62.2977 \\
& \hline 59.4138 \\
& \hline 94.6375 \\
& \hline 86.0015 \\
& \hline
\end{aligned}
$$
$k$

The electric field and its angle generated by conductor

$$
\begin{aligned}
& \mathrm{E}_{\mathrm{p}}\left(\mathrm{x}_{\mathrm{o}}, \mathrm{y}_{\mathrm{o}}, \mathrm{k}\right):=\frac{\mathrm{Q}_{\mathrm{k}}}{2 \cdot \pi \cdot \varepsilon_{\mathrm{o}} \cdot \operatorname{dis}\left(\mathrm{x}_{\mathrm{O}}, \mathrm{y}_{\mathrm{o}}, \mathrm{k}\right)} \\
& \phi_{\mathrm{p}}\left(\mathrm{x}_{\mathrm{O}}, \mathrm{y}_{\mathrm{o}}, \mathrm{k}\right):=\operatorname{acos}\left(\frac{\mathrm{x}_{\mathrm{o}}-\mathrm{x}_{\mathrm{k}}}{\operatorname{dis}\left(\mathrm{x}_{\mathrm{O}}, \mathrm{y}_{\mathrm{O}}, \mathrm{k}\right)}\right)
\end{aligned}
$$

The $x$ and $y$ component of this field:

$$
\begin{aligned}
& \mathrm{E}_{\mathrm{px}}\left(\mathrm{x}_{\mathrm{o}}, \mathrm{y}_{\mathrm{o}}, \mathrm{k}\right):=\mathrm{E}_{\mathrm{p}}\left(\mathrm{x}_{\mathrm{o}}, \mathrm{y}_{\mathrm{o}}, \mathrm{k}\right) \cdot \cos \left(\phi_{\mathrm{p}}\left(\mathrm{x}_{\mathrm{o}}, \mathrm{y}_{\mathrm{o}}, \mathrm{k}\right)\right) \\
& \mathrm{E}_{\mathrm{py}}\left(\mathrm{x}_{\mathrm{o}}, \mathrm{y}_{\mathrm{o}}, \mathrm{k}\right):=\mathrm{E}_{\mathrm{p}}\left(\mathrm{x}_{\mathrm{o}}, \mathrm{y}_{\mathrm{o}}, \mathrm{k}\right) \cdot \sin \left(\phi_{\mathrm{p}}\left(\mathrm{x}_{\mathrm{o}}, \mathrm{y}_{\mathrm{o}}, \mathrm{k}\right)\right)
\end{aligned}
$$

$$
\begin{aligned}
& \left|\mathrm{E}_{\mathrm{py}}\left(\mathrm{x}_{\mathrm{O}}, \mathrm{y}_{\mathrm{o}}, \mathrm{k}\right)\right|= \\
& \begin{array}{|l|}
\hline .5561 \\
\hline 2.4954 \\
\hline 2.5083 \\
\hline 0.1587 \\
\hline 0.1922 \\
\hline
\end{array}
\end{aligned}
$$$$
\begin{aligned}
& \left|\mathrm{E}_{\mathrm{px}}\left(\mathrm{x}_{\mathrm{O}}, \mathrm{y}_{\mathrm{o}}, \mathrm{k}\right)\right|= \\
& \begin{array}{|r|}
\hline 1.2396 \\
\hline 0.8459 \\
\hline 0.2976 \\
\hline 0.0729 \\
\hline 1.1172 \cdot 10^{-3} \\
\hline
\end{array}
\end{aligned}
$$

Field generated by the negative (image) charges on the conductors

The distances between the image charges and a selected point in the space; 


$$
\begin{aligned}
& \operatorname{Dis}\left(\mathrm{x}_{\mathrm{o}}, \mathrm{y}_{\mathrm{O}}, \mathrm{k}\right):=\sqrt{\left(\mathrm{x}_{\mathrm{o}}-\mathrm{x}_{\mathrm{k}}\right)^{2}+\left(\mathrm{y}_{\mathrm{o}}+\mathrm{y}_{\mathrm{k}}\right)^{2}} \\
& \mathrm{E}_{\mathrm{n}}\left(\mathrm{x}_{\mathrm{O}}, \mathrm{y}_{\mathrm{o}}, \mathrm{k}\right):=\frac{-\mathrm{Q}_{\mathrm{k}}}{2 \cdot \pi \cdot \varepsilon_{\mathrm{o}} \cdot \operatorname{Dis}\left(\mathrm{x}_{\mathrm{O}}, \mathrm{y}_{\mathrm{o}}, \mathrm{k}\right)}
\end{aligned}
$$

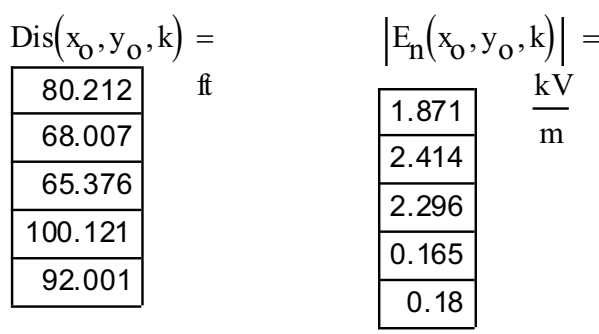

$$
\begin{aligned}
& \Phi_{\mathrm{n}}\left(\mathrm{x}_{\mathrm{O}}, \mathrm{y}_{\mathrm{O}}, \mathrm{k}\right):=\operatorname{acos}\left(\frac{\mathrm{x}_{\mathrm{o}}-\mathrm{x}_{\mathrm{k}}}{\operatorname{Dis}\left(\mathrm{x}_{\mathrm{O}}, \mathrm{y}_{\mathrm{O}}, \mathrm{k}\right)}\right) \\
& \Phi_{\mathrm{n}}\left(\mathrm{x}_{\mathrm{O}}, \mathrm{y}_{\mathrm{O}}, \mathrm{k}\right)= \\
& \begin{array}{|l|}
\hline 54.1302 \\
\hline 72.8973 \\
\hline 96.1466 \\
\hline 66.7638 \\
\hline 89.6886 \\
\hline
\end{array}
\end{aligned}
$$$$
\mathrm{E}_{\mathrm{nx}}\left(\mathrm{x}_{\mathrm{o}}, \mathrm{y}_{\mathrm{o}}, \mathrm{k}\right):=\mathrm{E}_{\mathrm{n}}\left(\mathrm{x}_{\mathrm{o}}, \mathrm{y}_{\mathrm{o}}, \mathrm{k}\right) \cdot \cos \left(\Phi_{\mathrm{n}}\left(\mathrm{x}_{\mathrm{o}}, \mathrm{y}_{\mathrm{o}}, \mathrm{k}\right)\right)
$$$$
\mathrm{E}_{\mathrm{ny}}\left(\mathrm{x}_{\mathrm{o}}, \mathrm{y}_{\mathrm{o}}, \mathrm{k}\right):=\mathrm{E}_{\mathrm{n}}\left(\mathrm{x}_{\mathrm{o}}, \mathrm{y}_{\mathrm{o}}, \mathrm{k}\right) \cdot \sin \left(\Phi_{\mathrm{n}}\left(\mathrm{x}_{\mathrm{o}}, \mathrm{y}_{\mathrm{o}}, \mathrm{k}\right)\right)
$$$$
\left|\mathrm{E}_{\mathrm{nx}}\left(\mathrm{x}_{\mathrm{O}}, \mathrm{y}_{\mathrm{O}}, \mathrm{k}\right)\right|=
$$

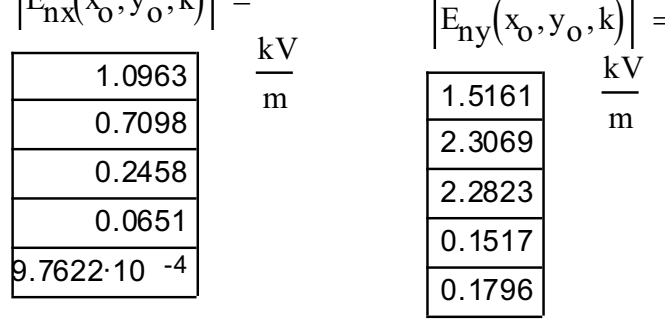

The components of the total field are;

$$
\begin{aligned}
& \mathrm{E}_{\mathrm{x}}\left(\mathrm{x}_{\mathrm{o}}, \mathrm{y}_{\mathrm{o}}\right):=\sum_{\mathrm{k}}\left(\mathrm{E}_{\mathrm{px}}\left(\mathrm{x}_{\mathrm{o}}, \mathrm{y}_{\mathrm{o}}, \mathrm{k}\right)+\mathrm{E}_{\mathrm{nx}}\left(\mathrm{x}_{\mathrm{O}}, \mathrm{y}_{\mathrm{o}}, \mathrm{k}\right)\right) \\
& \mathrm{E}_{\mathrm{x}}\left(\mathrm{x}_{\mathrm{o}}, \mathrm{y}_{\mathrm{o}}\right) \mid=171.362 \frac{\mathrm{V}}{\mathrm{m}} \\
& \mathrm{E}_{\mathrm{y}}\left(\mathrm{x}_{\mathrm{O}}, \mathrm{y}_{\mathrm{o}}\right):=\sum_{\mathrm{k}}\left(\mathrm{E}_{\mathrm{py}}\left(\mathrm{x}_{\mathrm{o}}, \mathrm{y}_{\mathrm{o}}, \mathrm{k}\right)+\mathrm{E}_{\mathrm{ny}}\left(\mathrm{x}_{\mathrm{O}}, \mathrm{y}_{\mathrm{o}}, \mathrm{k}\right)\right) \\
& \left|\mathrm{E}_{\mathrm{y}}\left(\mathrm{x}_{\mathrm{o}}, \mathrm{y}_{\mathrm{o}}\right)\right|=0.1485 \frac{\mathrm{kV}}{\mathrm{m}} \\
& \mathrm{E}_{\text {total }}\left(\mathrm{x}_{\mathrm{o}}, \mathrm{y}_{\mathrm{o}}\right):=\sqrt{\left(\mathrm{E}_{\mathrm{x}}\left(\mathrm{x}_{\mathrm{o}}, \mathrm{y}_{\mathrm{o}}\right)\right)^{2}+\left(\mathrm{E}_{\mathrm{y}}\left(\mathrm{x}_{\mathrm{o}}, \mathrm{y}_{\mathrm{o}}\right)\right)^{2}}
\end{aligned}
$$$$
\left|\mathrm{E}_{\text {total }}\left(\mathrm{x}_{\mathrm{O}}, \mathrm{y}_{\mathrm{O}}\right)\right|=0.198 \frac{\mathrm{kV}}{\mathrm{m}} \quad \mathrm{x}_{\mathrm{O}}:=-400 \mathrm{ft} . .400 \mathrm{ft}
$$ 


$$
\begin{aligned}
& \mathrm{I}_{\mathrm{ph}_{0}}:=1354 \mathrm{~A} \\
& \mathrm{I}_{\mathrm{ph}_{1}}:=\mathrm{I}_{\mathrm{ph}_{0}} \cdot \mathrm{e}^{-\mathrm{i} \cdot 120 \mathrm{deg}} \\
& \mathrm{I}_{2}:=\mathrm{Iph}_{0} \cdot \mathrm{e}^{-\mathrm{i} \cdot 240 \mathrm{deg}} \\
& \mathrm{I}_{\mathrm{ph}}=\left(\begin{array}{c}
1.354 \\
-0.677-1.173 \mathrm{i} \\
-0.677+1.173 \mathrm{i}
\end{array}\right) \mathrm{kA}
\end{aligned}
$$

\section{Field generated by phase currents}

Distance between conductor $\mathrm{k}$ and a selected point with coordinates of $\left(\mathrm{x}_{0}, \mathrm{y}_{\mathrm{o}}\right)$;

$$
\begin{aligned}
& \mathrm{k}:=0 . .2 \\
& \operatorname{dis}\left(\mathrm{x}_{\mathrm{O}}, \mathrm{y}_{\mathrm{O}}, \mathrm{k}\right):=\sqrt{\left(\mathrm{x}_{\mathrm{O}}-\mathrm{x}_{\mathrm{k}}\right)^{2}+\left(\mathrm{y}_{\mathrm{O}}-\mathrm{y}_{\mathrm{k}}\right)^{2}} \\
& \operatorname{dis}\left(\mathrm{x}_{\mathrm{O}}, \mathrm{y}_{\mathrm{O}}, \mathrm{k}\right)= \\
& \hline 75.4321 \\
& \hline 62.2977 \\
& \hline 59.4138 \\
& \hline
\end{aligned}
$$

The magnetic field and its angle generated by conductor $k$;

$$
\begin{aligned}
& \mathrm{H}_{\mathrm{ph}}\left(\mathrm{x}_{\mathrm{O}}, \mathrm{y}_{\mathrm{O}}, \mathrm{k}\right):=\frac{\mathrm{I}_{\mathrm{ph}_{\mathrm{k}}}}{2 \cdot \pi \cdot \operatorname{dis}\left(\mathrm{x}_{\mathrm{O}}, \mathrm{y}_{\mathrm{O}}, \mathrm{k}\right)} \\
& \mathrm{H}_{\mathrm{ph}}\left(\mathrm{x}_{\mathrm{o}}, \mathrm{y}_{\mathrm{o}}, \mathrm{k}\right)= \\
& \begin{array}{|r|}
\hline 9.3728 \cdot 10^{-3} \\
\hline-5.6744 \cdot 10^{-3} 9.8284 \mathrm{i} \cdot 10^{-3} \\
\hline-5.9499 \cdot 10^{-3}+0.0103 \mathrm{i} \\
\hline \mathrm{m}
\end{array}
\end{aligned}
$$

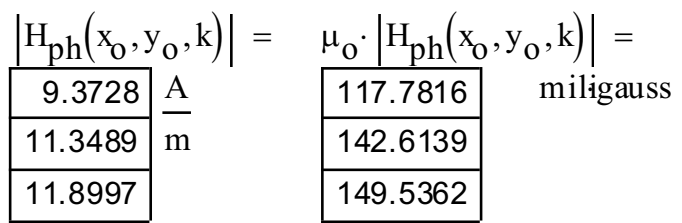

$$
\begin{aligned}
& \phi_{\mathrm{p}}\left(\mathrm{x}_{\mathrm{o}}, \mathrm{y}_{\mathrm{o}}, \mathrm{k}\right):=\operatorname{acos}\left(\frac{\mathrm{x}_{\mathrm{o}}-\mathrm{x}_{\mathrm{k}}}{\operatorname{dis}\left(\mathrm{x}_{\mathrm{o}}, \mathrm{y}_{\mathrm{o}}, \mathrm{k}\right)}\right) \\
& \phi_{\mathrm{p}}\left(\mathrm{x}_{\mathrm{O}}, \mathrm{y}_{\mathrm{O}}, \mathrm{k}\right)= \\
& 51.459 \text { deg } \\
& 71.274 \\
& 96.766
\end{aligned}
$$

$$
\begin{aligned}
& \mathrm{H}_{\text {total }}\left(\mathrm{x}_{\mathrm{o}}, \mathrm{y}_{\mathrm{o}}\right):=\sqrt{\left(\left|\mathrm{H}_{\mathrm{x}}\left(\mathrm{x}_{\mathrm{O}}, \mathrm{y}_{\mathrm{o}}\right)\right|\right)^{2}+\left(\left|\mathrm{H}_{\mathrm{y}}\left(\mathrm{x}_{\mathrm{O}}, \mathrm{y}_{\mathrm{o}}\right)\right|\right)^{2}} \\
& \mathrm{H}_{\text {total }}\left(\mathrm{x}_{\mathrm{O}}, \mathrm{y}_{\mathrm{o}}\right)=7.605 \frac{\mathrm{A}}{\mathrm{m}}
\end{aligned}
$$

The field density is:

$\mathrm{B}_{\text {total }}\left(\mathrm{x}_{\mathrm{o}}, \mathrm{y}_{\mathrm{o}}\right):=\mu_{\mathrm{o}} \cdot \mathrm{H}_{\text {total }}\left(\mathrm{x}_{\mathrm{O}}, \mathrm{y}_{\mathrm{o}}\right)$

$$
\begin{aligned}
& \mathrm{B}_{\text {total }}\left(\mathrm{x}_{\mathrm{O}}, \mathrm{y}_{\mathrm{O}}\right)=9.557 \times 10^{-6} \mathrm{~T} \\
& \mathrm{~B}_{\text {total }}\left(\mathrm{x}_{\mathrm{O}}, \mathrm{y}_{\mathrm{O}}\right)=95.566 \mathrm{miligauss} \\
& \mathrm{x}_{\mathrm{O}}:=-150 \mathrm{~m} . .150 \mathrm{~m}
\end{aligned}
$$

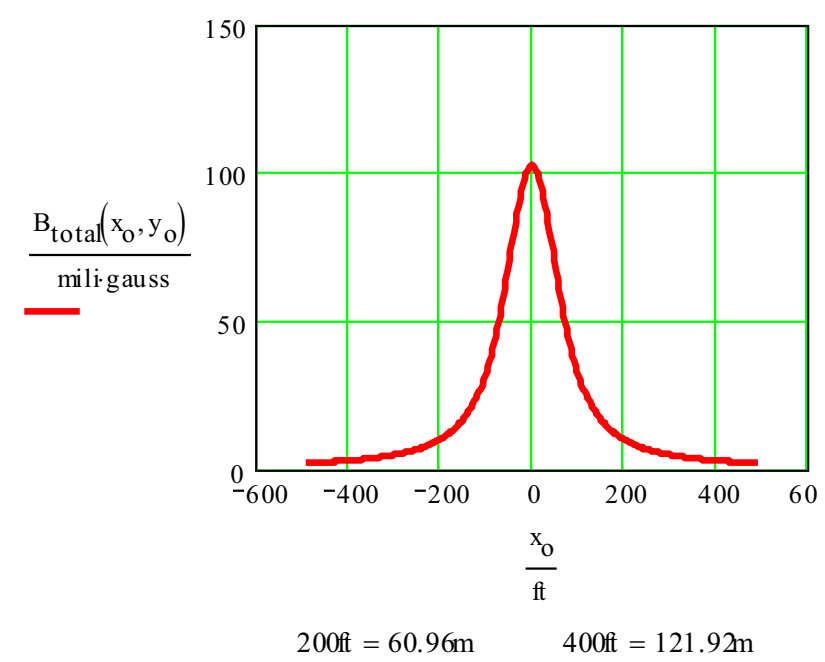

Figure 10. Variation of $\boldsymbol{B}$ with distance from conductors of a TL.

The graph in Figure 10 depicts the variation of magnetic field intensity with the distance from the 
conductors. The magnetic field intensity is at maximum directly underneath the middle conductor (about 96 milligauss) and reduces rapidly when one moves away from the conductors. The acceptable magnetic field strength is about 120 milli-gauss for the transmission line. The calculated magnetic field strength is 96 milli-gauss which is within the acceptable range of the transmission line.

\section{Discussion}

The rate of the peak electrical load in PNG has grown steadily over the years. Recent projections by PPL put the near-term annual growth at about $2.3 \%$ over a 2.5 year period. Based on this growth rate, PNG's peak power demand is expected to increase from $210 \mathrm{MW}$ in 2012 to $347 \mathrm{MW}$ in 2026.

The peak load, although growing at a smaller rate, will continue to require expansion of utility transmission systems. The subject of this project is the electrical design of a $345-\mathrm{kV}$ transmission line that will be required to achieve this expansion and interconnect the Ramu and Rouna grids. It concerns the calculation of specific electrical design phenomena associate with $345-\mathrm{kV}$ EHV transmission. The analysis procedures cover the areas of transmission circuit performance, insulation design, corona performance, and induction phenomena.

The design of the transmission line is critical because of its significant impact on the cost and performance on the transmission addition. While carrying out the design, due considerations are given to the mechanical, electrical, environmental and economical aspect of this project. However, much of the design calculations are done on the electrical aspects of the transmission line.

For the insulator string selections, according to IEEE Standard 1313.2-1999, the number of standard I-string units for a moderate contamination severity is 24 which is proven in calculations and recommended to be used henceforth in this project. Further, the safety clearance distance calculated between conductors, between conductor and structure, and between conductor and ground is within the safety distance specified by the National Safety Code.

The EMF intensity is strongest right underneath the middle conductor of the transmission line. In this design, the maximum electric and magnetic field intensity is $0.196-\mathrm{kV} / \mathrm{m}$ and 96 milli-gauss respectively. The calculated results are within the acceptable range of transmission line.

There are other calculations performed include transmission line impedance and capacitance, corona generation and loss, audible noise, and radio interference which are not covered in this paper. The calculations are done and verified in accordance to the relevant established standards such as IEEE and NESC (and NEC) to ensure the design conforms to these standards.

\section{Conclusion}

The goal of this design project proposal is achieved in two-fold. Firstly, the rationale to undertake such project as this is presented to justify the need for a $345-\mathrm{kV}$ transmission line to interconnect the isolated power grids in the country. Secondly, the initial detailed design is done for a $345-\mathrm{kV}$ electric transmission line conforming to the relevant standards.

This project when implemented will alleviate the power woes in the country and maximize the economic benefits. The principle economic advantage would be a reduction in reserve generating capacity by pooling existing reserves. The amount of reserve capacity that must be built by individual networks to ensure reliable operation when supplies are short can be reduced by sharing reserves within the interconnected network. Substantial costs could also be saved from pooling reserves from private generations which are often very expensive.

\section{References}

1. ADB Technical Assistance Consultant's Report, Papua New Guinea: Power Sector Development Plan (Financed by the Japan Special Fund), VisionRI Connexion Services Private Limited, Rohini, New Delhi, 2009.

2. Ramu Transmission System Reinforcement Project, Japan International Cooperation Agency, 2013. [Online]. From: http://www.jica.go.jp/png/english/activities/activity 16.html [Accessed on 12 March 2015].

3. General Electric Company and Electric Power Research Institute, Transmission Line Reference Book - 345-kV and Above. 2nd edition. EPRI, Palo Alto: CA, 1982.

4. T. Abe, PNG Business Advantage Conference, 20120731PS-SP MD PNG Business Advantage Conference. Port Moresby, 2012.

5. M. Morauta, Public Statement - 20111206PS NEC Yonki Mananda Stanley power submissions. Ministry of Public Enterprises, Pacific Place Building, Port Moresby, Papua New Guinea, 2011.

6. M. Nalu, Geothermal power potential huge: Micah. The National Newspaper, Port Moresby, 2015.

7. J. Fisher, (Compiled Lecture Notes), Electric Power Transmission Design, Department of Electrical \& Communication Engineering, PNG University of Technology, Lae, 2014.

8. Supplemental Municipal Consultation Filing - The Interstate Reliability Project, Section 3 - Technical Project Specifications, Connecticut Light \& Power, Connecticut: USA, 2011.

9. APEC Energy Demand and Supply Outlook - 5th Edition Papua New Guinea. 2013. [Online]. From: publications.apec.org/filedownload.php?filename $=2013$ ewg_EDSO5_V2_P apua_New_Guinea.pdf\&id $=1389$ _toc. [Accessed on 5 March 2015].

10. Edison Electric Institute, EHV Transmission Line Reference Book. Edison Electric Institute. 750 Third Ave., New York, 1968. 
11. M. Isaka, L. Mofor and H. Wade, Renewable energy opportunities and challenges in the Pacific Islands region, Pacific Lighthouses, IRENE, 2013.

12. More power for city - Extra electricity supply to cover Games demand. 2015. The National Newspaper, pp. $1 \& 3$.

13. Technical Aspects of Grid Interconnection, [Online]. From: http://www.un.org/esa/sustdev/publications/energy/c hapter2.pdf. [Accessed on 24 February 2015]. 